\title{
Modelling the Dependency of a Non-Steady Diffusion on Temperature of a Conductive Material
}

\author{
Stephen I. Okeke ${ }^{1}$, Damasus Arinze Nworah ${ }^{2}$, Jummai Adamu Tutuwa (PhD) ${ }^{3}$ \\ ${ }^{1}$ Department of Mathematics/Statistics, Ignatius Ajuru University of Education, Port Harcourt, Nigeria \\ ${ }^{2,3}$ Bioresources Development Centre, National Biotechnology Development Agency \\ Jalingo, Taraba State, Nigeria.
}

\begin{abstract}
The concentration of a diffusing species is a function of both time and position, $u=u(x, t)$. The species used in this paper was a copper which was allowed to diffuse into a bar of copper (a host metal). The analytic method was used to establish the concentration of the material with the independent variables $x$ andt. The effect of temperature on concentration and the thermal diffusivity of a material $D$ were determined using numerical simulation. The results were showed on diverse plots at different temperatures.
\end{abstract}

Keywords: Numerical Simulation, Thermal diffusivity, Temperature, Concentration, Activation Energy.

\section{INTRODUCTION}

Temperature has a great effect on the rate of metal electrochemical corrosion. It is the measure of hotness or coldness expressed in terms of any of numerous capricious scales and signifying the direction, in which heat energy will instinctively flow; that is from a hotter body which is one at a higher temperature to a colder body which is one at a lower temperature. An increase or decrease on the temperature of system at equilibrium is a stress to the system. In the Haber-Bosch process, the concentration of $\mathrm{NH}_{3}$ in the system decreases, as there is an increase in the concentrations of $\mathrm{N}_{2}$ and $\mathrm{H}_{2}$. Thus, an increase in temperature enhances the reverse reaction (endothermic direction). The concentration of $\mathrm{NH}_{3}$ in the system increases as there is a decrease in the concentration of $\mathrm{N}_{2}$ and $\mathrm{H}_{2}$. Thus, a decrease in temperature enhances the forward reaction. Meetham (1991) showed that in most industries, transportation and power generation occur as a result of high temperature of materials by investigating on the high-temperature aluminum alloys, steels and nickel alloys. Temperature is a measure of a quality of a state of a material. One effect that leads to $\mathrm{CO}$ structure involves its formation by passing air over surfeit carbon at high temperature. The early product (carbon dioxide) equilibrates with the residual hot carbon, resulting to carbon monoxide. $\mathrm{CO}_{2}$ formation is no-expense-spared at lower temperature whereas $\mathrm{CO}$ is the major product above $800^{\circ} \mathrm{C}$. The conductance is a measure of how easily those charge particles move through a solution or material usually measured in Siemens, $\mathrm{S}$ while the conductivity is the conductance (S) measured across a specified distance through a material or solution usually measured in Siemens per centimeter, $\mathrm{S} / \mathrm{cm}$. The activation energy is the energy that must be provided to compounds to result in a chemical reaction. It was introduced in 1889 by the Swedish scientist Svante Arrhenius. His equation gives the quantitative center of the relation between the activation energy and the rate at which a reaction proceeds. Diffusion is a vital aspect of most chemical and biological phenomena. In chemical processes, diffusion is frequently the central principle driving many reactions. For instance, a few crystals of sugar in a glass of water will slowly dissolve over time. This occurs since there is a net movement of sugar molecules into the water medium while in biological systems, diffusion occurs across membranes in every cell as well as through the body. As an example, oxygen is at a higher concentration inside arteries and arterioles, when compared with the oxygen levels in actively respiring cells. There are factors that affect the diffusion; they include: temperature, area of interaction, concentration difference, particle size and diffusing species.

Miao, Li and Chen (2014) investigated on the thermo-physical features for four rock types which included the granite, granodiorite, gabbro and gernet amphibolites ranging from room temperature to $1,173 \mathrm{~K}$ and specific heat capacity using laserflash method and heat flux differential scanning calorimetry respectively. Their result was that the rock thermal diffusivity and conductivity declined as the temperature increased and approached a constant value at high temperatures. 
Wen, Lu, Xiao and Deng (2015) carried out a scientific work on the thermal properties of coal and rocks using the laser-flash apparatus LFA457. Their result suggested that the method was able to determine accurately the thermophysical properties for rocks; when the temperature increased, there was a decrease in the thermal diffusivity and thermal conductivity.

In line with Mehrer and Stolwijk (2009), diffusion is a scientific discipline that is base on various cornerstones such as the continuum theory, the Brownian motion, solid-state and atomistics of diffusion in materials which had driven an important contribution to Einstein, Arrhenius, Perrin, von Hevesy and Bardeen. In terms of interdiffusion, atoms tend to migrate from regions of high concentration to regions of low concentration in an alloy. Thus, diffusion is a stepwise migration of atoms from lattice site to lattice site. Hence, a self-diffusion.

In this study, we are interested to model the dependency of diffusion on temperature of a conductive material (copper tin rod) which is a metallic material that is an extreme case of the problem imposed by conductivity.

A copper, $\mathrm{Cu}$ is a chemical element, a soft, malleable, ductile reddish-brown metal with very high thermal and electrical conductivity with atomic number 29 which is important to plumbing, electrical wiring; living organisms such as in fish and other vertebrates including human which has formed mainly in the liver, muscle and bone. Copper (II) salts are commonly encountered compounds which have been used extensively and in olden times as pigments which also exist in an aqueous solution.

In nature, copper occurs in the aquatic environment in low concentration (Woody \& O'Neal, 2012). Nordberg et al., 2007 suggested that seawater copper concentrations are generally less than 1 part per billion (ppb). Davis et al., 2000 suggested that a high aquatic copper concentrations mainly occurs copper mining and smelting facilities and in developed areas. The said aquatic habitats are subject to copper pollution (Nriagu 1979, Davis et. al, 2000); NAS (1977) in Woody and O'Neal (2012) highlighted that the copper is highly lethal to freshwater fish in soft water at low concentration ranging from $10-20 \mathrm{ppb}$.

Scientists such as Gupta, et. al, 1999, Gomez and Bosecker (1999), Deng, et. al, 2007 and Green-Ruiz, et. al, 2008 in Aston, et. al. (2010) reported an increase in loading capabilities of metals with increasing temperature.

Aston, et. al. (2010) examined on the cause of cell condition, $\mathrm{pH}$ and temperature on lead $(\mathrm{Pb})$, zinc and copper sorption to acidithiobacillus caldus strain using Langmuir model. Their result showed that far less copper was improved from viable cells than any other metal or cell state.

\section{MATHEMATICAL FORMATION}

Following Okeke and Nwagor (2019) in Philibert (2006), considering the concentration of the diffusant at a point $x$ meters along a bar tin rod at $t$ represented by $u(x, t)$, then a one dimensional heat equation is

$\frac{\partial u}{\partial t}=\mathrm{D} \frac{\partial^{2} u}{\partial x^{2}}, \quad 0 \leq x \leq \mathrm{L}, \quad t \geq 0$.

where $u=u(x, t)$ is the dependent variable, and $D$ is a constant coefficient due to the bar rod material.

\section{Pre-existing conc., u0 of copper}

\section{Surface Conc., $u_{s}$ of $\mathrm{Cu}$}

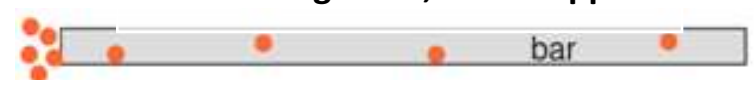

Thermal diffusivity measures the rate of transfer of heat of a material from the hot end to the cold end. It is given as $D=\frac{k}{\rho c_{p}}$, where: $k$ is the thermal conductivity $\left(\frac{W}{m \cdot K}\right), c_{p}$ is specific heat capacity $(J /(\mathrm{kg} / \mathrm{K})), \rho$ is density $\left(\mathrm{kg} / \mathrm{m}^{3}\right)$ and $\rho c_{p}$ is the volumetric heat capacity $\left.U /\left(\frac{K}{m^{3}}\right)\right)$.

Let $\mathrm{D}$ represents the thermal diffusivity of a material,

$\mathrm{M}$ is the modified frequency factor (pre-exponential factor),

$\mathrm{Q}$ is the activation energy ( $\mathrm{J} /$ mole $)$,

$\mathrm{R}$ is the universal gas constant $(8.314 \mathrm{~J} / \mathrm{mol}-\mathrm{K})$ and 
$\mathrm{T}$ is the absolute temperature $(\mathrm{K})$, then, following Arrhenius-type plot equation, the effect of temperature and activation parameters for some systems can be estimated as

$$
D=M \operatorname{Exp}\left(-\frac{Q}{R T}\right)
$$

The diffusion coefficient, D increases with increasing temperature, T.

In a linear form, equation (2) can be written as:

In $D=\operatorname{In} M-\frac{Q}{R T}$.

For two thermal diffusivities at two different temperatures, equation (3) leads to (4) and (5):

$\operatorname{In} D_{1}=\operatorname{In} M-\frac{Q}{R T_{1}}$

$\operatorname{In} D_{2}=\operatorname{In} M-\frac{Q}{R T_{2}}$

(5) - (4): $\operatorname{In} D_{2}-\operatorname{In} D_{1}=\operatorname{In} M-\frac{Q}{R T_{2}}-\operatorname{In} M+\frac{Q}{R T_{1}}$

This implies that $\operatorname{In} D_{2}-\operatorname{In} D_{1}=-\frac{Q}{R T_{2}}+\frac{Q}{R T_{1}}$, so that:

$\operatorname{In} D_{2}-\operatorname{In} D_{1}=\frac{Q}{R T_{1}}-\frac{Q}{R T_{2}}$

$\operatorname{In} \frac{D_{2}}{D_{1}}=\frac{Q}{R}\left(\frac{1}{T_{1}}-\frac{1}{T_{2}}\right)$

$2.303 R \log \frac{D_{2}}{D_{1}}=Q\left(\frac{1}{T_{1}}-\frac{1}{T_{2}}\right)$

This last equation becomes: $\quad \log \frac{D_{2}}{D_{1}}=\frac{Q}{2.303 R}\left(\frac{1}{T_{1}}-\frac{1}{T_{2}}\right)$

This implies that from (3): $\operatorname{In} D-\operatorname{In} M=-\frac{Q}{R T}$.

Thus from (9), as $T$

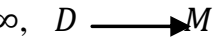

Solving equation (1) using separation of variable to get:

$u(x, t)=C e^{-D k^{2} t}\left(c_{1} \operatorname{Cosk} x+c_{2} \operatorname{Sink} x\right)$

This implies that, $u(x, t)=C e^{-k^{2} D t}(\operatorname{Coskx}+\operatorname{Sinkx})$

Hence, $(x, t)=C e^{-k^{2} t M \exp \left(-\frac{Q}{R T}\right)}(\operatorname{Coskx}+\operatorname{Sinkx}): \mathrm{c}_{1}=\mathrm{c}_{2}=1$.

Where $C$ is the constant formed from integrating process in the absolute temperature. 
International Journal of Advances in Scientific Research and Engineering (ijasre), Vol 6 (10), October -2020

\section{RESULTS AND DISCUSSION}

The results are presented below with examined simulated data.

Table 1.3.1 A Table Showing the Diffusion Data.

\begin{tabular}{|c|c|c|c|c|c|c|}
\hline \multirow{2}{*}{$\begin{array}{l}\text { Diffuning } \\
\text { Speries }\end{array}$} & \multirow{2}{*}{$\begin{array}{l}\text { Ilowet } \\
\text { Metal }\end{array}$} & \multirow[b]{2}{*}{$D_{i n}\left(m^{2} / s\right)$} & \multicolumn{2}{|c|}{ Articution Energr $Q_{d}$} & \multicolumn{2}{|c|}{ Calculated Values } \\
\hline & & & $\mathrm{ks} / \mathrm{mul}$ & el/etem & $\left.T \gamma^{\circ} \mathrm{C}\right)$ & $D\left(m^{2} / s\right)$ \\
\hline $\mathrm{Fe}$ & $\begin{array}{l}\alpha-F_{c} \\
(B C C)\end{array}$ & $2.8 \times 10^{-4}$ & 251 & 2.60 & $\begin{array}{l}500 \\
900\end{array}$ & $\begin{array}{l}3.0 \times 10^{-21} \\
1.8 \times 10^{-13}\end{array}$ \\
\hline $\mathrm{Fe}$ & $\begin{array}{l}\gamma-\mathrm{Fe} \\
(\mathrm{FCC})\end{array}$ & $5.0 \times 10^{-5}$ & 284 & 2.94 & $\begin{array}{r}900 \\
1100\end{array}$ & $\begin{array}{l}1.1 \times 10^{-17} \\
7.8 \times 10^{-16}\end{array}$ \\
\hline C & $\alpha-\mathrm{Fe}$ & $6.2 \times 10^{-7}$ & 80 & 0.83 & $\begin{array}{l}500 \\
900\end{array}$ & $\begin{array}{l}2.4 \times 10^{-12} \\
1.7 \times 10^{-10}\end{array}$ \\
\hline $\mathrm{C}$ & $\gamma \cdot \mathrm{Fe}$ & $2.3 \times 10^{-5}$ & 148 & 1.53 & $\begin{array}{r}900 \\
1100\end{array}$ & $\begin{array}{l}5.9 \times 10^{-12} \\
5.3 \times 10^{-11}\end{array}$ \\
\hline $\mathrm{Cu}$ & $\mathrm{Cu}$ & $7.8 \times 10^{-5}$ & 211 & 2.19 & 500 & $4.2 \times 10^{-19}$ \\
\hline $\mathrm{Zn}$ & $\mathrm{Cu}$ & $2.4 \times 10^{-5}$ & 189 & 1.96 & 500 & $4.0 \times 10^{-18}$ \\
\hline Al & Al & $2.3 \times 10^{-4}$ & 144 & 1.49 & 500 & $4.2 \times 10^{-14}$ \\
\hline $\mathrm{Cu}$ & Al & $6.5 \times 10^{-3}$ & 136 & 1.41 & 500 & $4.1 \times 10^{-14}$ \\
\hline $\mathrm{Mg}$ & Al & $1.2 \times 10^{-4}$ & 131 & 1.35 & 500 & $1.9 \times 10^{-13}$ \\
\hline $\mathrm{Cu}$ & $\mathrm{Ni}$ & $2.7 \times 10^{-5}$ & 256 & 2.65 & 500 & $1.3 \times 10^{-22}$ \\
\hline
\end{tabular}

Source: E. A. Brandes and G. B. Brook (Editors), Smüthells Metals Reference Book, 7th edition, ButterworthHeinemann, Oxford, 1992.

From the Table 1.3.1: For the diffusing species $(\mathrm{Cu})$ to the host metal $(\mathrm{Cu})$, the temperatures $873 \mathrm{~K}, 973 \mathrm{~K}, 1073 \mathrm{~K}$, $1173 \mathrm{~K}$ and $1273 \mathrm{~K}$ with their corresponding diffusion coefficients are gotten from (6).

Thus,

$D_{2}=D_{1} e^{\left[\frac{Q}{R}\left(\frac{1}{T_{1}}-\frac{1}{T_{2}}\right)\right]}$

The equation (13) helps to formulate the diffusion coefficients at the different temperatures $(773 \mathrm{~K}-1273 \mathrm{~K})$.

Table 1.3.2 A Table Showing the Calculated Diffusion Data for the Temperature 773K-1273K.

\begin{tabular}{|l|l|}
\hline Temperature $(\mathrm{K})$ & Diffusion Coefficient $\left(\mathrm{m}^{2} / \mathrm{s}\right)$ \\
\hline 873 & $1.8053 \mathrm{e}-017$ \\
\hline 973 & $3.5818 \mathrm{e}-016$ \\
\hline 1073 & $4.0721 \mathrm{e}-015$ \\
\hline 1173 & $3.0586 \mathrm{e}-014$ \\
\hline 1273 & $1.6736 \mathrm{e}-013$ \\
\hline
\end{tabular}

The plot for the simulated data above is shown below. 
International Journal of Advances in Scientific Research and Engineering (ijasre), Vol 6 (10), October -2020

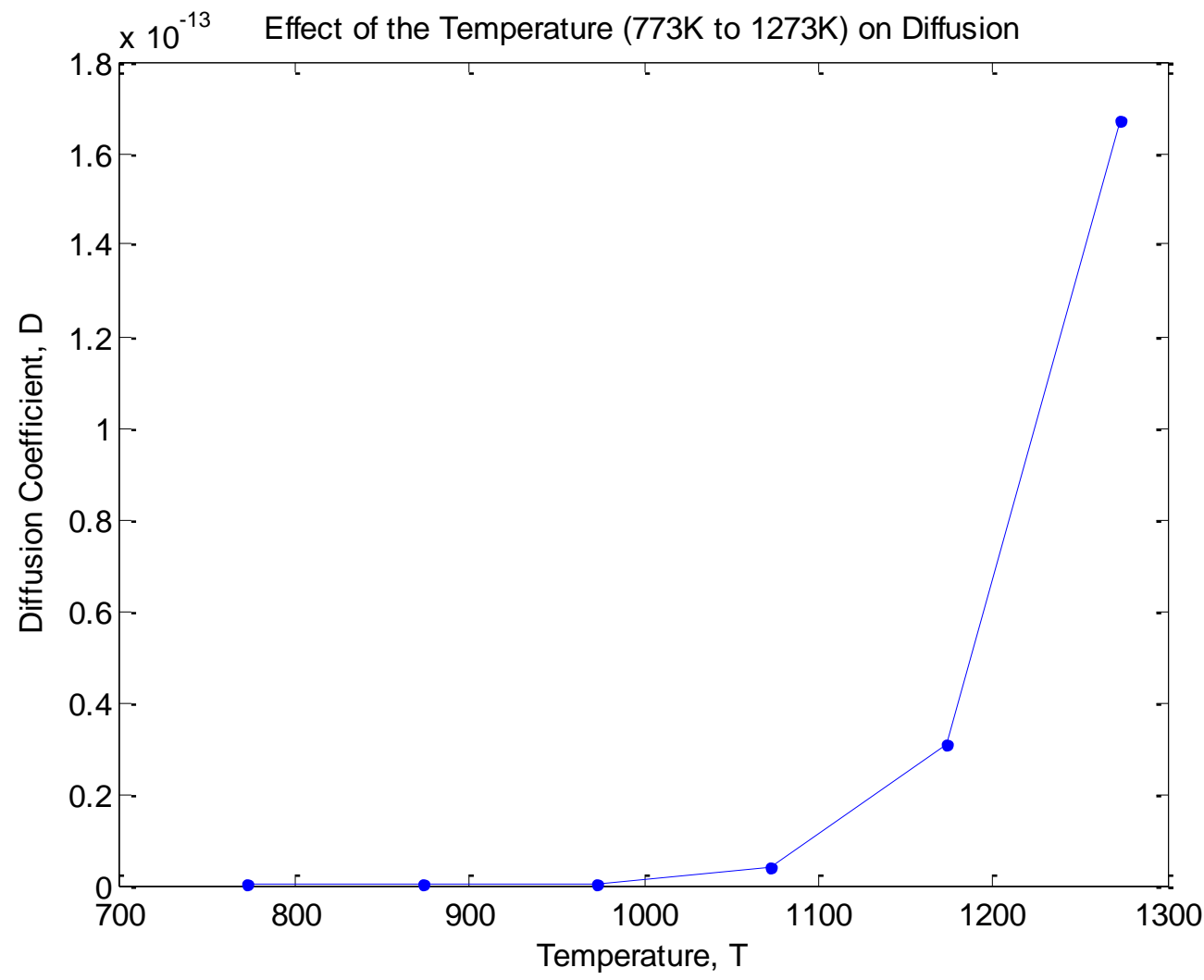

Figure 2: A Graph Showing the Effect of the Temperature from 773K-1273K.

The plot for linearization for the Table 1.3.2 is shown below.

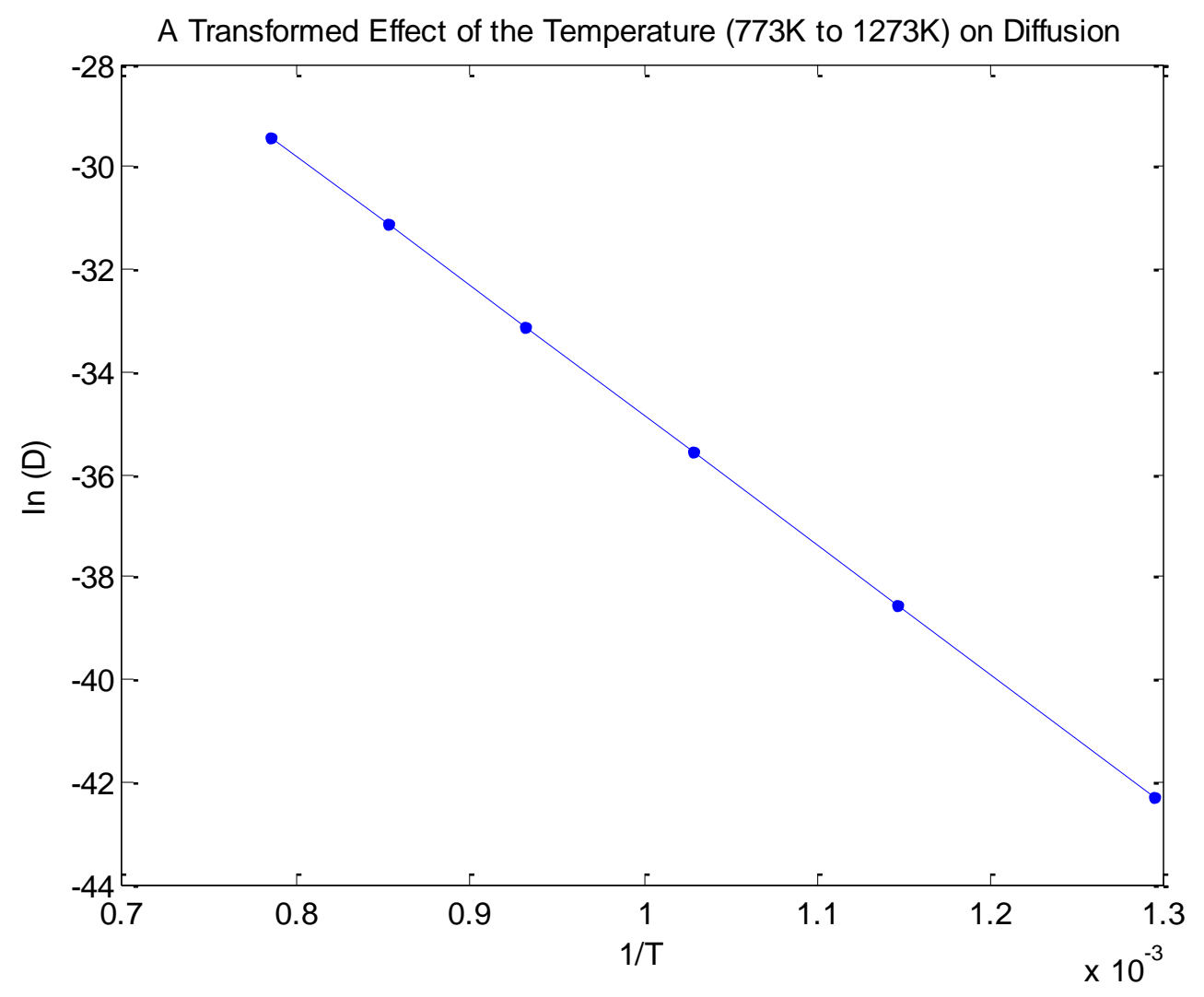

Figure 3: A Graph Showing a Transformed Effect of the Temperature from 773K-1273K.

With help of equation (13), table 1.3.3 is formed. 
International Journal of Advances in Scientific Research and Engineering (ijasre), Vol 6 (10), October -2020

Table 1.3.3A Table Showing the Calculated Diffusion Data for the Temperature 773K-1128K.

\begin{tabular}{|l|l|}
\hline Temperature $(\mathrm{K})$ & Diffusion Coefficient $\left(\mathrm{m}^{2} / \mathrm{s}\right)$ \\
\hline 784 & $1.4018 \mathrm{e}-019$ \\
\hline 843 & $6.4156 \mathrm{e}-018$ \\
\hline 938 & $1.3534 \mathrm{e}-016$ \\
\hline 1033 & $1.6295 \mathrm{e}-015$ \\
\hline 1128 & $1.2902 \mathrm{e}-014$ \\
\hline
\end{tabular}

The plot for the simulated data above is shown below.

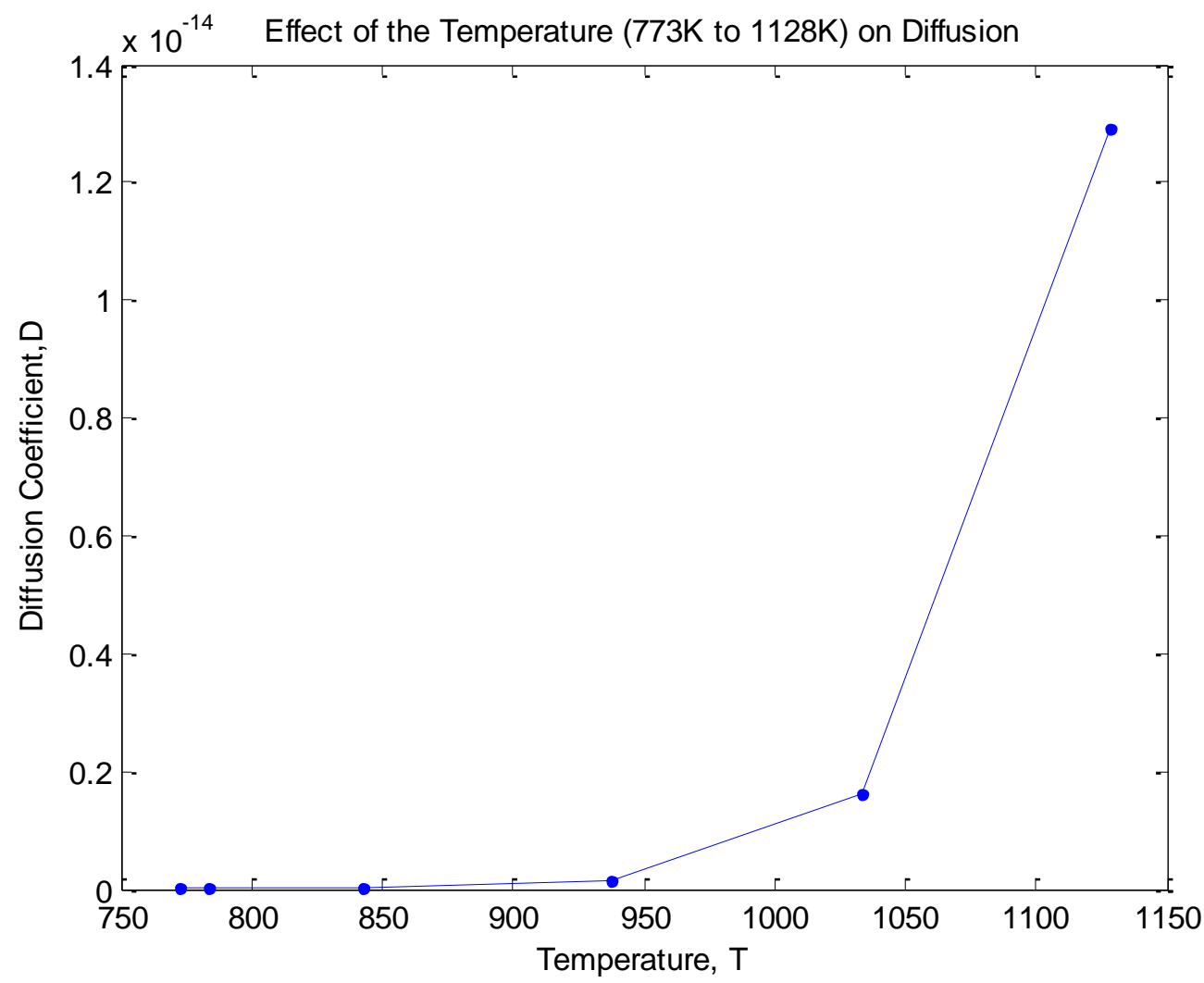

Figure 4: A Graph Showing the Effect of the Temperature from 773K-1128K.

The plot for In (D) against 1/T for the Table 1.3.3 is shown below. 
International Journal of Advances in Scientific Research and Engineering (ijasre), Vol 6 (10), October -2020

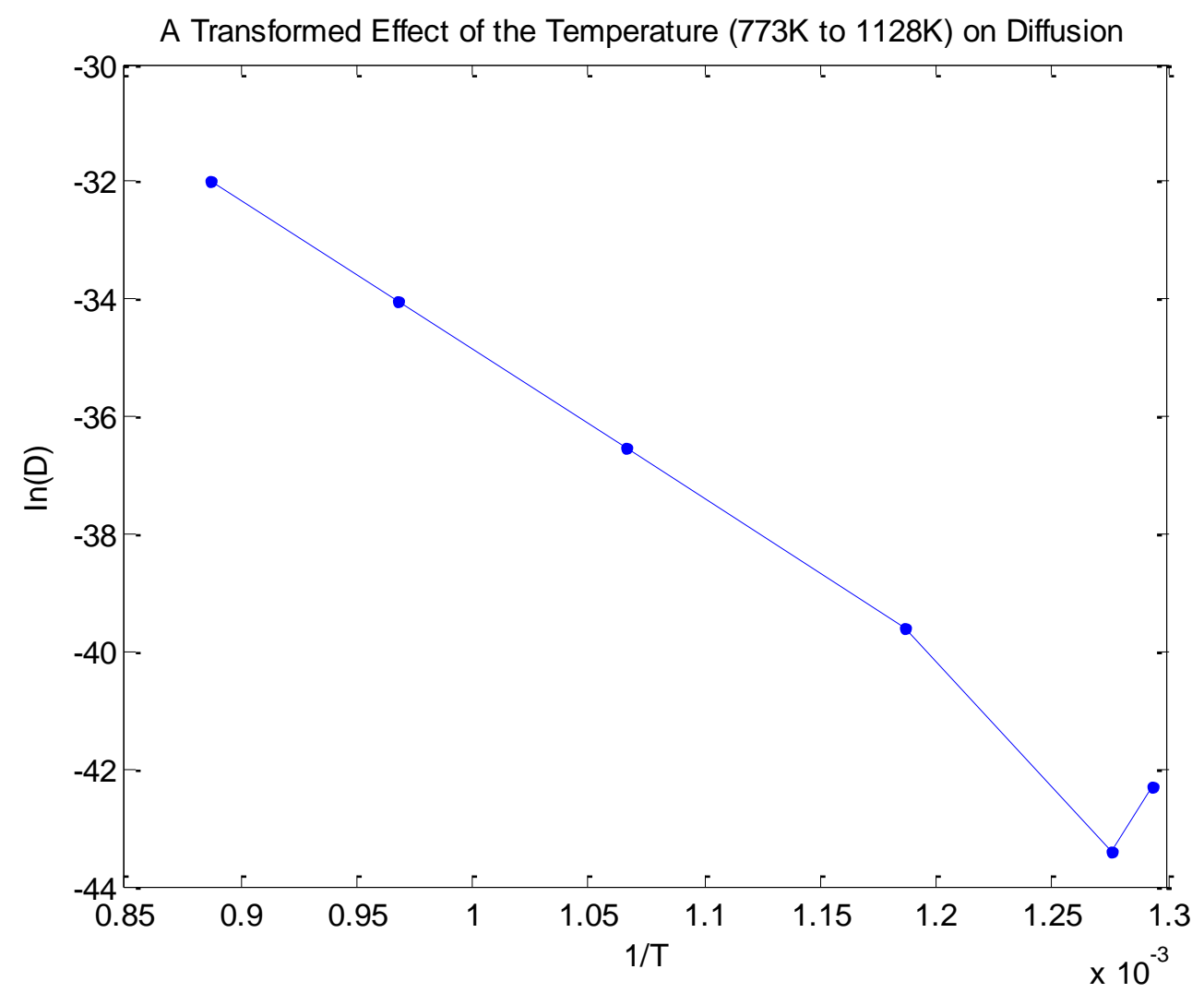

Figure 5: A Graph Showing a Transformed Effect of the Temperature from 773K-1128K.

Table 1.3.4 A Table Showing the Calculated Diffusion Data for the Temperature 773K-4773K.

\begin{tabular}{|l|l|}
\hline Temperature $(\mathrm{K})$ & Diffusion Coefficient $\left(\mathrm{m}^{2} / \mathrm{s}\right)$ \\
\hline 2773 & $8.0749 \mathrm{e}-009$ \\
\hline 3273 & $3.2684 \mathrm{e}-008$ \\
\hline 3773 & $9.1328 \mathrm{e}-008$ \\
\hline 4273 & $2.0065 \mathrm{e}-007$ \\
\hline 4773 & $3.7380 \mathrm{e}-007$ \\
\hline
\end{tabular}

The plot for the simulated data above is shown below. 
International Journal of Advances in Scientific Research and Engineering (ijasre), Vol 6 (10), October -2020

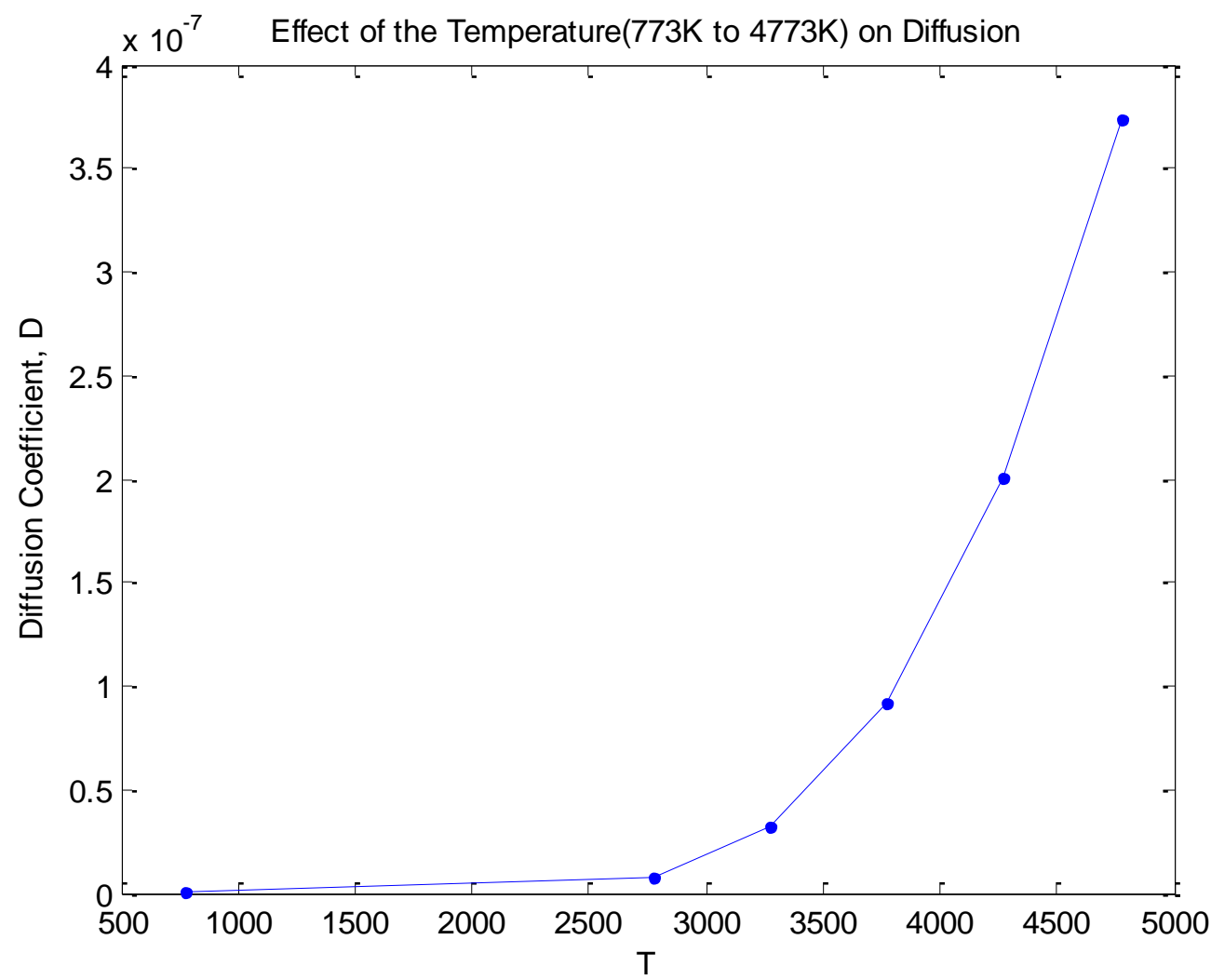

Figure 6: A Graph Showing the Effect of the Temperature from 773K-4773K.

The plot for linearization for the Table 1.3.4 is shown below.

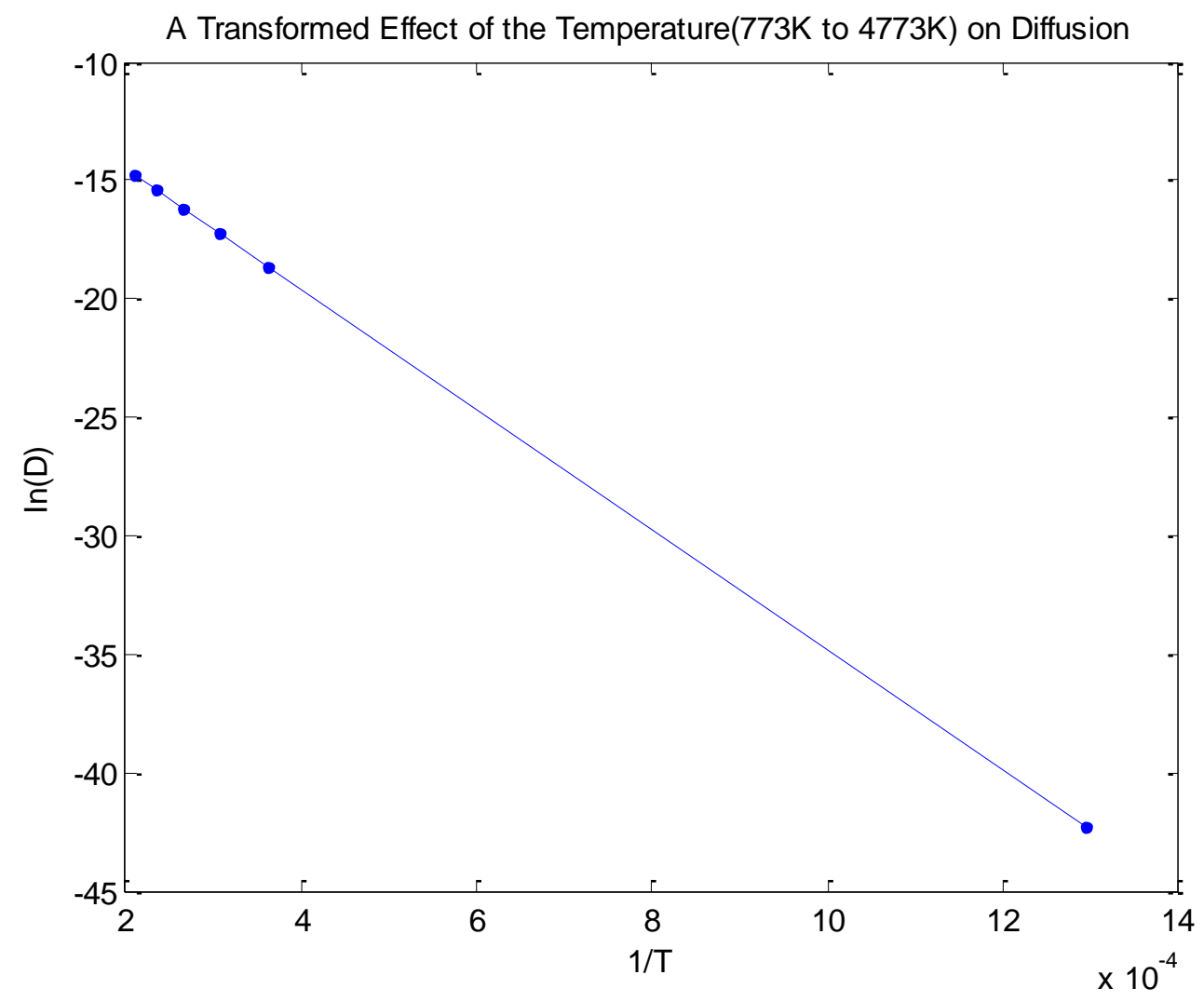

Figure 7: A Graph Showing a Transformed Effect of the Temperature from 773K-4773K.

From (1), as $\mathrm{L} \rightarrow \infty$ : the following boundary conditions (B.C) for an infinite slab (a tin bar rod) are obtained. Boundary Condition: 
at $\mathrm{t}=0, \mathrm{u}=\mathrm{u}_{0}$ for $0 \leq x \leq \infty$, and

at $\mathrm{t}>0, \mathrm{u}=\mathrm{u}_{\mathrm{s}}$ for $x=0$ ( a constant surface concentration)

for $t_{j+1}>t_{j}>0: j=1,2,3, \ldots$

$\mathrm{u}=\mathrm{u}_{0}$ for $\mathrm{x}=\infty$

The solution u can be interpreted (Atkinson, et. al, 2009) as the concentration of the diffusing species at position $\mathrm{x}$ and time $\mathrm{t}$. The assumption made here was that there is negligible resistance to mass transfer at the surface of the object.

One important solution to equation (1) for the semi-infinite solid (a tin bar rod) is

$\frac{u(x, t)-u_{0}}{u_{s}-u_{0}}=1-\operatorname{erf}\left(\frac{x}{2 \sqrt{D t}}\right)$

Where $\mathrm{u}_{\mathrm{x}}$ or $\mathrm{u}(\mathrm{x}, \mathrm{t})=$ concentration at $\mathrm{x}, \mathrm{u}_{0}=$ initial concentration of species at $\mathrm{t}=0, \mathrm{u}_{\mathrm{s}}=$ surface concentration of species at $\mathrm{x}=0$. $\operatorname{erf}(x)=$ error function $=\frac{2}{\sqrt{\pi}} \int_{0}^{z} e^{-y^{2}} d y$, whose values are given below.

Table 1.3.5 A Table Showing the Error Function Values

\begin{tabular}{llllll}
\hline \multicolumn{1}{c}{$\boldsymbol{z}$} & $\operatorname{erf}(z)$ & $z$ & $\operatorname{erf}(z)$ & $z$ & $\operatorname{erf}(z)$ \\
\hline 0 & 0 & 0.55 & 0.5633 & 1.3 & 0.9340 \\
0.025 & 0.0282 & 0.60 & 0.6039 & 1.4 & 0.9523 \\
0.05 & 0.0564 & 0.65 & 0.6420 & 1.5 & 0.9661 \\
0.10 & 0.1125 & 0.70 & 0.6778 & 1.6 & 0.9763 \\
0.15 & 0.1680 & 0.75 & 0.7112 & 1.7 & 0.9838 \\
0.20 & 0.2227 & 0.80 & 0.7421 & 1.8 & 0.9891 \\
0.25 & 0.2763 & 0.85 & 0.7707 & 1.9 & 0.9928 \\
0.30 & 0.3286 & 0.90 & 0.7970 & 2.0 & 0.9953 \\
0.35 & 0.3794 & 0.95 & 0.8209 & 2.2 & 0.9981 \\
0.40 & 0.4284 & 1.0 & 0.8427 & 2.4 & 0.9993 \\
0.45 & 0.4755 & 1.1 & 0.8802 & 2.6 & 0.9998 \\
0.50 & 0.5205 & 1.2 & 0.9103 & 2.8 & 0.9999
\end{tabular}

Interpolation is used to determine any value between values of two entries in the table.

The formula below simplifies it.

$\operatorname{Erf}(z)=\frac{z-z_{0}}{z_{1}-z_{0}}\left[\operatorname{erf}\left(z_{1}\right)-\operatorname{erf}\left(z_{0}\right)\right]+\operatorname{erf}\left(z_{1}\right)$

Illustrated Example 1: Considering a diffusing species $(\mathrm{Cu})$ into a host pure metal $(\mathrm{Cu})$ with the examined temperatures $($ from Table 1.3.4) and their corresponding diffusion coefficients. If the surface concentration is maintained at $0.2 \mathrm{wt} \% \mathrm{Cu}$. The concentrations from $2 \mathrm{~mm}$ to $12 \mathrm{~mm}$ from the surface after 50 seconds to 300 seconds respectively are simulated and shown on plots.

From (15): $u(x, t)=\left(u_{s}-u_{0}\right)\left[1-\operatorname{erf}\left(\frac{x}{2 \sqrt{D t}}\right)\right]+u_{0}$

Table 1.3.6 A Table Showing the Simulated Data from Illustrated Example 1

\begin{tabular}{|l|l|l|l|l|l|}
\hline $\mathrm{x}(\mathrm{m})$ & $\mathrm{t}($ seconds $)$ & $\mathrm{T}(\mathrm{K})$ & $\mathrm{D}$ & $\operatorname{erf}(\mathrm{z})$ & $\mathrm{u}(\mathrm{x}, \mathrm{t})$ \\
\hline 0.002 & 50 & 773 & $4.2 \times 10^{-19}$ & 1.000 & 0.00 \\
\hline 0.004 & 100 & 2773 & $8.0749 \mathrm{e}-009$ & 0.9984 & $3.292590385972627 \mathrm{e}-004$ \\
\hline 0.006 & 150 & 3273 & $3.2684 \mathrm{e}-008$ & 0.944650355492137 & 0.011069928901573 \\
\hline 0.008 & 200 & 3773 & $9.1328 \mathrm{e}-008$ & 0.814365350124814 & 0.037126929975037 \\
\hline 0.010 & 250 & 4273 & $2.0065 \mathrm{e}-007$ & 0.681904363116498 & 0.063619127376700 \\
\hline 0.012 & 300 & 4773 & $3.7380 \mathrm{e}-007$ & 0.577032216225337 & 0.084593556754933 \\
\hline
\end{tabular}




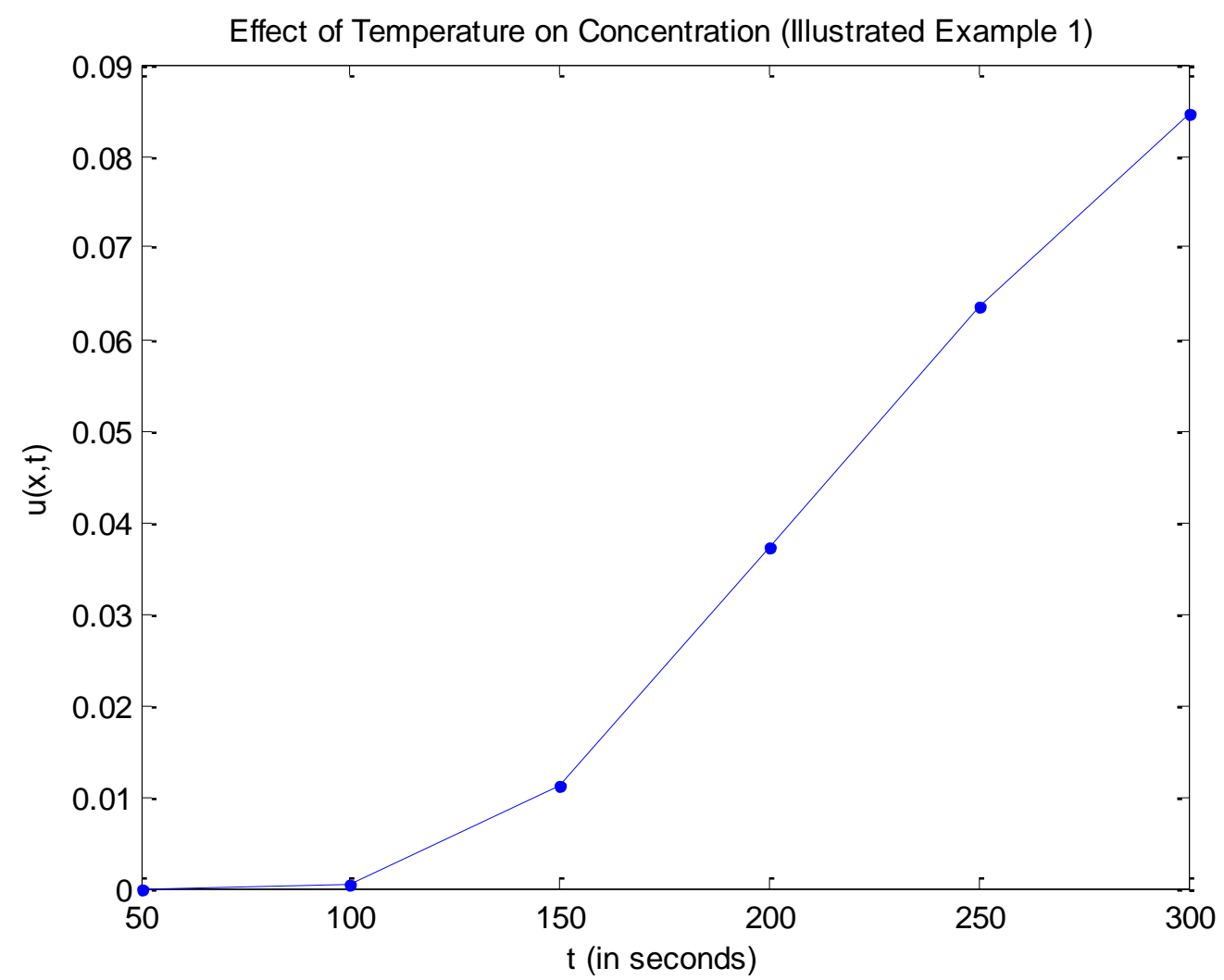

Figure 8: A Graph Showing the Effect of the Temperature on Concentration from 773K-4773K at Given Points of $x$ and $t$.

\section{CONCLUSION}

In this paper, the effect of temperature on concentration of a conductive material was studied. From the investigation, the following observations have been drawn.

1. From the figures 2, 4 and 6, the diffusion coefficients increased as a result of significant increase in the temperatures from 773 to $4773 \mathrm{~K}$.

2. The figure (8) showed that the concentration of the material increased dues to diverse increase on temperatures. Most materials that allow operation at high temperature are essential in most industries from material producing and processing to transportation and power generation. There is a need for varying the data parameters by decreasing the temperatures to investigate their effect on the concentration of the modelled conductive material.

3. High temperature reduces material stiffness and strength while low temperature increases material stiffness and strength.

\section{REFERENCES}

[1] C. Gomez, K. Bosecker (1999). Leaching Heavy Metals from Contaminated Soil using Thiobacillus Ferrooxidans or Thiobacillus thiooxidans. J. Geomicrobiol, 16, 233-244.

[2] C. Green-Ruiz, V. Rodriguez- Tirado, B. Gomez-Gil (2008). Cadmium and Zinc Removal from Aqueous Solutions by Bacillus Jeotgali: pH, Salinity, and Temperature Effects. Bioresour. Technol. 99, 750-762.

[3] Davis, RA, AT Welty, J Borrego, JA Morales, JG Pendon, JG Ryan, 2000. Rio Tinto estuary (Spain): 5000 years of pollution. Environmental Geology 39(10): 1107-1116.

[4] Dr. Carol Ann Woody \& Sarah Louise O'Neal (2012). Effects of Copper on Fish and Aquatic Resources. Fisheries Research and Consulting in Anchorage, Alaska.

[5] E. A. Brandes and G.B. Book (Editors), Smithells Metals Reference Book, 7th Edition, Butterworth-Heinemann, Oxford, 1992. 
International Journal of Advances in Scientific Research and Engineering (ijasre), Vol 6 (10), October -2020

[6] Effect of Temperature. Retrieved from https://courses.lumenlearning.comcheminter/chapter/effect-of-temperature on Thursday, 27th August 2020.

[7] G.W. Meetham (1991). High- Temperature Materials- a general review. Journal of Materials Science 26, 853-860.

[8] Helmut Mehrer, Nicolaas A. Stolwijk (2009). Heroes and Highlights in the History of Diffusion. The Open-Access Journal for the Basic Principles of Diffusion Theory, Experiment and Application, 1, 1-32.

[9] Hu Wen, Jun-hui Lu, Yang Xiao, Jun Deng (2015). Temperature Dependence of Thermal Conductivity, Diffusion, and Specific Heat Capacity for Coal and Rocks from Coalfield. Therochimica Acta, 619, 41-47.

[10] Jean Philibert (2006). One and a Half-Century of Diffusion: Fick, Einstein, Before and Beyond The Open-Access Journal for the Basic Principles of Diffusion Theory, Experiment and Application, 4, 1-19.

[11] John E. Aston, William A. Apel, Brady D. Lee, Brent M. Peyton (2010). Journal of Hazardous Materials, $184,34-41$.

[12] Kendall Atkinson, Weimin Han, David Stewart (2009). Numerical Solution of Ordinary Differential Equations, A John Wiley \& Sons, Inc., Hoboken, New Jersey, pp. 131.

[13] Khadom, A . A., Yaro, A. S., Abdul Amir H.k., Ahmed S. AlTaie, Ahmed Y. Musa

(2009). The Effect of Temperature and Acid Concentration on Corrosion of Low Carbon Steel in Hydrochloric Acid Media, American Journal of Applied Sciences, 6(9), pp.1403-1409.

[14] L. Deng, X. Zhu, X. Wang, Y. Su, H.Su (2007). Biosorption of Copper (II) from Aqueous Solutions by Green Alga Cladophora Fascicularis, Biodegradation, 18, 393-402.

[15] Norberg, GF, BA Fowler, M Nordberg, and LT Friberg, 2007. Handbook in the Toxicology of Metals. Elsevier NY.

[16] Nriagu, JO. 1979a. Global Inventory of Nature and Anthropogenic emissions of Trace Metals to the Atmosphere, Nature, 279: 409-411

[17] Nriagu, J.O. (Ed.), 1979b. The Global Copper Cycle. Copper in the Environment, Part 1: Ecological Cycling, John Wiley, NY.

[18] Nriagu, JO. 1979c. Copper in the Atmosphere and Precipitation, Pgs. 45-75 in J.O. Nriagu (Editor). Copper in the Environment, Part 1: Ecological Cycling, John Wiley, NY.

[19] Nriagu, JO. 1979d. The Global Copper Cycle. Pgs. 1-17 in J.O. Nriagu (Editor). Copper in the Environment, Part 1: Ecological Cycling, John Wiley, NY.

[20] Stephen I. Okeke and Peters Nwagor (2019). Numerical Stability of Fick's Second Law to Heat Flow. International Journal of Transformation in Applied Mathematics and Statistics, 2(2), 21-30.

[21] S. Q Miao. H.P. Li. G. Chen (2014). Temperature Dependence of Thermal Diffusivity, Specific Heat Capacity, and Thermal Conductivity for Several Types of Rocks. J. Them Anal Calorim, 1057-1063. Doi: 10.1007/s10973-013-3427-2.

[22] V.K. Gupta, D. Mohan, S. Sharma, K.T. Park (1999). Removal of Chromium (VI) from Electroplating Industry Waste Material, Environmentalist, 19, 129-136. 